ABDI: Jurnal Pengabdian dan Pemberdayaan Masyarakat ISSN: 2656-369X (Print), 2684-8570 (Online)

Volume 1 No. 2, Desember 2019

http://abdi.ppj.unp.ac.id/index.php/abdi

Email: abdi@ppj.unp.ac.id

DOI: https://doi.org/10.24036/abdi.vli2.10

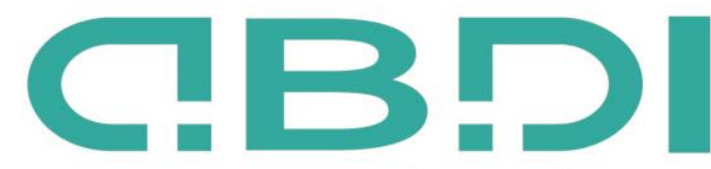

ABDI: JURNAL PENGABDIAN DAN PEMBERDAYAAN MASYARAKAT

\title{
Bimbingan Pra Nikah Bagi Calon Pengantin dalam Membentuk Keluarga Sakinah di Kanagarian Kambang Kecamatan Lengayang Kabupaten Pesisir Selatan
}

\author{
Riza Wardefi \\ Jurusan Ilmu Agama Islam Universitas Negeri Padang \\ Email: rizawardefi@ fis.unp.ac.id
}

\begin{abstract}
Abstrak
Tingginya tingkat perceraian di kalangan keluarga di Indonesia khususnya di Sumatera Barat mengidentifikasikan adanya suatu permasalahan yang cukup krusial. Keluarga sakinah mawaddah wa rahmah yang diidamkan oleh setiap keluarga muslim menjadi sulit tercapai. Salah satu penyebab persoalan tersebut di atas adalah akibat kurangnya pemahaman dari kedua belah pihak tentang makna berkeluarga dalam Islam, tanggung jawab dalam keluarga,dan kurangnya pemahaman tentang hak dan kewajiban suami dan isteri dalam berkeluarga. Untuk mengatasi masalah tersebut diperlukan suatu pelatihan dan sosialisasi tentang konsep berkeluarga dalam Islam dan upaya yang dapat dilakukan dalam menciptakan keluarga sakinah mawaddah wa rahmah. Pelatihan ini diperuntukan bagi para pemuda dan pemudi yang mendekati usia layak nikah. Adapun luaran yang diharapkan dari pelatihan ini adalah draft publikasi ilmiah dalam bentuk jurnal terakreditasi.
\end{abstract}

Kata Kunci: Bimbingan Pra Nikah, Keluarga Muslim, Hak dan Kewajiban Suami-Istri

\section{Abstract}

The high rate of divorce among families in Indonesia, especially in West Sumatra that identifies a very crucial problem. The sakinah mawaddah warahmah family that is desired by every Muslim family becomes difficult to achieve. One of the causes is the result of an understanding of both parties about the meaning of family in Islam, responsibilities in the family, and understanding of the rights and obligations of husband and wife in the household. Solving the problem about the concept of family in Islam is needed and efforts by training and socialization that can be made to create a happy family (mawaddah wa rahmah). This training is intended for young men and women who are bride and groom. The outputs needed from this training are scientific publication and journals publication.

Keyword: Bride and Groom, Family, Mariage, Training

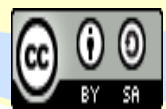




\section{Pendahuluan}

Keluarga adalah lembaga terkecil yang berperan dalam membentuk masyarakat, bahkan negara. Keluarga yang kuat lagi sehat secara fisik dan psikis akan menghasilkan masyarakat yang berkualitas baik. Demi membangun masyarakat berkualitas baik, maka dilakukan pembinaan terhadap keluarga agar terwujud keluarga sakinah, mawaddah wa rahmah.

Islam memandang keluarga sebagai bagian terpenting dalam kehidupan manusia, terutama dalam kebahagiaan dunia dan akhirat. Pentingnya kehidupan keluarga dalam pandangan Islam tidak hanya sebatas hubungan darah atau nasab tetapi memiliki makna yang jauh lebih dalam seperti aplikasi nilainilai kehidupan bermasyakat seperti kasih sayang, kedamaian, kepedulian, keteladanan, kedisiplinan, sopan santun, keikhlasan dan ketaqwaan. Selain itu keluarga adalah wadah atau tempat pembinaan dan penghasil generasi Islami yang diharapkan dalam masyarakat. Jika kuat nilai ke-Islaman maka akan terbina keharmonisan diantara keluarga dan masyarakat sekitar. Terutama penanaman nilai-niali dan pembentukan kepribadian yang kuat dan positif di kalangan anak-anak, suami dan istri di tengah masyarakat.

Secara sosiologi, keluarga berasal dari kata "kulawarga", kula berarti ras, dan "warga" berarti anggota, Maka "keluarga" diartikan sebagai hubungan darah. Secara umum keluarga dimaknai sebagai kelompok-kelompok orang yang disatukan oleh ikatan perkawinan, darah, atau adopsi yang memiliki susunan rumah tangga tersendiri, berinteraksi, berkomunikasi, memiliki peran sebagai ayah, ibu, dan anak. Secara struktural dan fungsional, keluarga berarti kehadiran dan ketidak hadiran anggota keluarga pada tugas-tugas dan fungsi-fungsi sosialnya. Beberapa pengertian keluarga secara Sosiologis menunjukkan terjalinnya hubungannya kuat diantara anggota keluarga baik secara lahir dan batin. Bailon dan Maglaya (1978) : Kerluarga merupakan dua atau lebih individu yang hidup dalam satu rumah tangga karena adanya hubungan darah, perkawinan, dan adopsi.

Keluarga harmonis, setidak-tidaknya dapat terlaksanakannya fungsi-fungsi keluarga secara baik dan tepat. Jika tidak terlaksana, maka akan menimbulkan persoalan atau problem dalam keluarga nantinya. Dalam pandangan Islam, keluarga yang harmonis disebut juga keluarga sakinah, mawaddah wa rahmah. Dalam kajian Sosiologi keluarga memiliki peran atau fungsi suami-istri diantaranya adalah; (1) Fungsi Reproduksi, (2) Fungsi Sosialisasi, (3) Fungsi Afeksi/ Cinta dan Kasih, (4) Fungsi Proteksi atau perlindungan, (5) Fungsi Ekonomi, (6) Fungsi Religius, (7) Fungsi Pendidikan, (8) Fungsi Rekreasi, (9) Fungsi Penentuan Status. Apabila kesembilan fungsi ini tidak berjalan baik, maka akan dapat menjadikan persoalan dalam kehidupan keluarga di dalam masyarakat. Untuk mencapai keluarga yang bahagia diperlukan upaya-upaya maksimal dari anggota keluarga terutama ayah dan ibu sebagai pemimpin dalam sebuah rumah tangga. Maka dari itu, sebulum pernikahan dilangsungkan perlu adanya pemahaman yang benar diantara kedua pengantin tentang makna dan tugas rumah tangga.

Menurut Ketua Pengadilan Agama Padang, M. Taufiq, HZ (2006:6) di pengadilan agama Padang angka perceraian di kota Padang menunjukkan tren meningkat. Di antara penyebab perceraian adalah tidak adanya keharmonisan dalam rumah tangga. Hal ini di antaranya dipicu oleh adanya pihak ketiga baik perselingkuhan atau pun dominasi pihak keluarga tertentu, kurang memahami antara suami dan isteri, tingginya ego salah satu pihak, tidak saling menghargai satu sama lain dan tidak terpenuhinya hak masing-masing suami dan isteri dalam rumah tangga. Jika ditinjau dari aspek kekerasan dalam rumah tangga di kota Padang misalnya, didominasi oleh penelantaran rumah tangga (70\%), kekerasan seksual 0\%, tindak kekerasan pisik 10\% dan tindak kekerasan psikis $20 \%$.

Salah satu penyebab persoalan tersebut di atas adalah akibat kurangnya pemahaman dari kedua belah pihak tentang makna berkeluarga dalam Islam, tanggung jawab dalam keluarga, kurangnya pemahaman tentang hak dan kewajiban suami dan isteri dalam berkeluarga. Kekurangan-kekurangan ini dapat menyebabkan sebuah keluarga sulit dalam menghadapi persoalan yang begitu banyak dalam mengayuh bahtera kehidupan berumah tangga, yang kemudian berakhir dengan kekerasan dalam rumah tangga (KDRT), penelantaran anggota keluarga baik yang dilakukan oleh ayah atau pun ibu, atau akhirnya bercerai. Semua ini membawa dampak besar bagi kelangsungan dan masa depan anak-anak dan keluarga bahkan masyarakat Indonesia.

Belakangan santer terdengar istilah pelakor, yakni akronim dari perebut lelaki orang. Istilah tersebut ditujukan kepada wanita yang merebut suami wanita lain dengan cara memisahkan sang suami 
dari keluarganya, sehingga banyak keluarga-keluarga rapuh yang akhirnya runtuh. Hal ini tentu sangat dilarang dalam agama. Rasulullah Saw. bersabda,

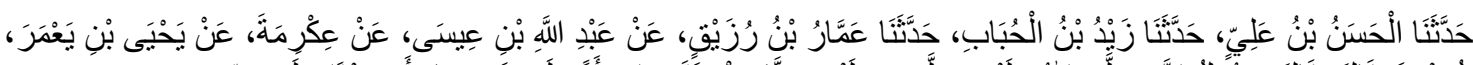

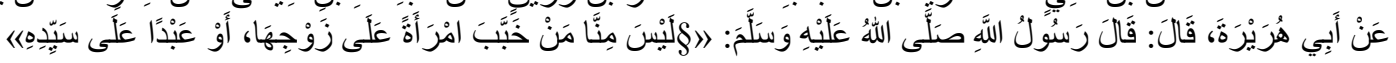

(رواه ابو داود)

Telah menceritakan kepada kami al-Hasan bin 'Ali, telah menceritakan kepada kami Zayd bin al-Hubab, telah menceritakan kepada kami'Ammar bin Ruzayq dari 'Abdullah bin 'Isa dari 'Ikrimah dari Yahya bin Ya'mar dari Abu Hurairah berkata, Rasulullah Saw. bersabda: "Bukanlah termasuk kaumku orang yang merusak hubungan seorang wanita dengan suaminya dan hubungan seorang hamba dari tuannya." (HR. Abu Dawud)

Untuk itu perlu adanya suatu pembekalan atau pembimbingan terhadap calon pengantin sebelum mereka mengarungi lautan rumah tangga yang mana sebahagian besar kehidupan individual manusia akan dihabiskan di sana. Seorang calon pegawai negeri saja disyaratkan mengikuti Latihan Pra Jabatan (LPJ) untuk membekali pegawai dalam menjalankan tugasnya sebagai abdi negara. Untuk bekerja di perusahaan-perusahaan diharuskan untuk magang atau pun training selama beberapa bulan. Apalagi untuk pernikahan yang pada akhirnya sangat menentukan kualitas masyarakat negara Indonesia di masa depan, jadi perlu kiranya sebelum menikah calon pengantin dan para remaja yang mendekati usia kawin diberi bimbingan dalam menjalankan fungsi-fungsinya dalam kehidupan berkeluarga nantinya.

Berdasarkan data yang diperoleh pada Kemenag Bimas Islam di daerah Sumbar seperti Kabupaten Pesisir Selatan di Kecamatan Lengayang pada tahun 2017 dapat diketahui adanya tiga persoalan pernikahan dalam keluarga, yaitu persoalan Thalak, Cerai dan Rujuk. Berikut dapat dikemukakan persoalan pernikahan dalam keluarga di Kecamatan Lengayang Kabupaten Pesisir Selatan;

Tabel 1. Data Persoalan Pernikahan Kecamatan Lengayang Kabupaten Pesisir Selatan

\begin{tabular}{clccc}
\hline No & \multicolumn{1}{c}{ Penyebab } & $\mathbf{2 0 1 1}$ & $\mathbf{2 0 1 2}$ & $\mathbf{2 0 1 3}$ \\
\hline 1 & Tidak Harmonis & 51.882 & 91.388 & 97.615 \\
\hline 2 & Tidak Tanggungjawab & 42.701 & 81.227 & 81.266 \\
\hline 3 & Ekonomi & 35.480 & 70.427 & 74.559 \\
\hline 4 & Gangguan Pihak Ketiga & 12.082 & 23.690 & 25.310 \\
\hline 5 & Cemburu & 5.824 & 10.524 & 9.338 \\
\hline 6 & Krisis Akhlak & 4.217 & 8.537 & 10.649 \\
\hline 7 & Kawin Paksa & 1.140 & 2.071 & 3.380 \\
\hline 8 & KDRT & 1.605 & 3.697 & 4.439 \\
\hline 9 & Poligami Tidak Sehat & 758 & 1.876 & 1.951 \\
\hline 10 & Cacat Biologis & 440 & 737 & 1.247 \\
\hline 11 & Menyakiti Mental & 432 & 1.108 & 1.491 \\
\hline 12 & Dihukum & 143 & 392 & 714 \\
\hline 13 & Politisi & 327 & 423 & 2.094 \\
\hline 14 & Kawin Bawah Umur & 184 & 432 & 600
\end{tabular}

Sumber: Bimas Kemenag Kab. Pesisir Selatan, 2018

Berdasarkan data di atas dapat diketahui bahwa persoalan utama terhadap rumahtangga adalah tidak harmonis, tidak bertanggungjawab dan ekonomi. Ketiga persoalan ini merupakan persoalan utama dalam rumahtangga. Rendahnya jumlah tindakan thalak, dan gugatan cerai dapat dilihat dari data berikut ini; 
Tabel 2. Status Perceraian di Kabupaten/Kota Sumatera Barat

\begin{tabular}{lccccc}
\hline \multirow{2}{*}{ Kabupaten/Kota } & \multicolumn{3}{c}{ Status Perkawinan } & & Jumlah \\
\cline { 2 - 5 } & Belum Kawin & Kawin & Cerai Hidup & Cerai Mati & \\
\hline Kabupaten & & & & & \\
\hline 1. Kep. Mentawai & 35.90 & 59.08 & 0.99 & 4.03 & 100.00 \\
\hline 2. Pesisir Selatan & 32.20 & 60.01 & 2.71 & 5.07 & 100.00 \\
\hline 3. Solok & 33.82 & 57.33 & 2.54 & 6.31 & 100.00 \\
\hline 4. Sijunjung & 31.73 & 60.27 & 2.38 & 5.62 & 100.00 \\
\hline 5.Tanah Datar & 32.79 & 56.18 & 3.32 & 7.71 & 100.00 \\
\hline 6. Padang Pariaman & 36.36 & 52.74 & 3.23 & 7.67 & 100.00 \\
\hline 7. Agam & 35.82 & 53.63 & 2.33 & 8.22 & 100.00 \\
\hline 8. Lima Puluh Kota & 29.84 & 60.31 & 2.74 & 7.11 & 100.00 \\
\hline 9. P a s a m a n & 35.77 & 54.84 & 2.49 & 6.89 & 100.00 \\
\hline 10. Solok Selatan & 33.41 & 59.18 & 2.14 & 5.27 & 100.00 \\
\hline 11. Dharmasraya & 30.57 & 62.64 & 2.14 & 4.65 & 100.00 \\
\hline 12. Pasaman Barat & 35.84 & 56.14 & 2.13 & 5.89 & 100.00 \\
\hline Kota & & & & & \\
\hline 13. Padang & 43.71 & 50.52 & 1.58 & 4.19 & 100.00 \\
\hline 14. Solok & 35.78 & 57.13 & 2.05 & 5.04 & 100.00 \\
\hline 15. Sawahlunto & 30.84 & 60.48 & 2.34 & 6.33 & 100.00 \\
\hline 16. Padang Panjang & 38.62 & 54.24 & 1.82 & 5.31 & 100.00 \\
\hline 17. Bukittinggi & 40.21 & 52.31 & 2.06 & 5.42 & 100.00 \\
\hline 18. Payakumbuh & 37.36 & 54.82 & 2.54 & 5.27 & 100.00 \\
\hline 19. Pariaman & 40.23 & 48.92 & 3.11 & 7.74 & 100.00 \\
\hline \multicolumn{1}{c}{ Jumlah } & 35.91 & 55.68 & 2.37 & 6.04 & 100.00 \\
\hline Sumber: BPJS, 2015 & & & & & \\
\hline
\end{tabular}

Dari Data di atas dapat diketahui bahwa angka cerai tertinggi berada di Kabupaten Payakumbuh dan Kota Payakumbuh. Sedang cerai mati tertinggi berada di daerah Kabupaten Agam. Dengan demikian pembekalan terhadap para remaja, pemuda dan pemudi yang sudah mendekati usia pernikahan untuk mempersiapkan diri dalam menempuh kehidupan berkeluarga sangat penting dilakukan. Para pemuda dan pemudi perlu diberi pengetahuan tentang pentingnya keluarga, bagaimana memilih jodoh, tanggungjawab suami dan istri dalam rumah tangga, mendidik anak secara bijak dan hal-hal lain perlu untuk menciptakan keluarga yang sakinah, mawaddah warahmah demi terwujudnya masyarakat madani.

\section{Metode Pelaksanaan}

Dalam pelaksanaan kegiatan ini diterapkan beberapa metode antara lain: 1). Untuk pemberian informasi digunakan metode seminar, diskusi dan tanya jawab, dimana para narasumber menyajikan makalah setelah itu dilanjutkan dengan diskusi dan tanya jawab. 2). Untuk pemecahan masalah-masalah yang dihadapi para peserta dalam mempersiapkan diri menjadi calon-calon suami-isteri maka digunakan metode diskusi, simulasi dan pemecahan masalah-masalah (problem solving) pembinaan keluarga yang dibimbing oleh pemateri yang ahli di bidangnya.

Mitra dalam kegiatan ini, mitra memberitahukan dan mengumpulkan seluruh anggotanya untuk menyampaikan rencana pelaksanaan kegiatan kita serta mengajak anggota mereka untuk berpartisipasi dalam kegiatan pelatihan ini. Sehingga peserta yang terlibat dalam kegiatan ini sesuai dengan target yang direncanakan di awal yaitu para pemuda atau anggota keluarga yang pemuda dan belum berkeluarga atau berumahtangga sebagai bimbingan pra-nikah menuju keluarga sakinah, mawaddah wa rahmah. Dalam hal ini pengabdian yang dilakukan adalah Bimbingan Pra Nikah Bagi Calon Pengantin 
Dalam Membentuk Keluarga Sakinah di Kanagarian Kambang Kecamatan Lengayang Kabupaten Pesisir Selatan.

\section{Hasil dan Pembahasan}

Kanagarian Kambang Kecamatan Lengayang merupakan wilayah perbukitan dan memilki luas lahan 27.645,3 Ha; terdiri dari 1.500 Ha lahan tanah sawah, $200 \mathrm{Ha}$ adalah lahan pekarangan, $800 \mathrm{Ha}$ adalah lahan tanah perladangan, dan $9.728 \mathrm{Ha}$ adalah lahan perbukitan. Melalui 8 kampung yang ada; Padang Panjang II, Padang Panjang I, Kambang Harapan, Kampung Baru, Lubuk Sarik, Ganting Kubang, Kampung Akad, dan Pasie Laweh. Untuk menuju wilayah ini kita menghabiskan waktu 131 $\mathrm{Km}$ dan ditempuh selam 4 setengah jam perjalan dengan mengendarai mobil. Sedangkan jarak dari ibu kota kabupaten sejauh $25 \mathrm{Km}$ dan Akses ke kota terdekat bagi masyarakat Kambang terdekat adalah menuju kota Painan yang ditempuh selama 1 jam perjalanan. Wilayah ini dapat dikatakan jauh dari akses kota. Informasi yang diperoleh dari televisi dan koran. Daerahnya telah memiliki listrik dan masih hijau. Masyarakatnya sangat ramah dan santun terhadap pendatang. Sedangkan jumlah penduduknya secara keseluruhan pada tahun 2017 adalah 11.328 jiwa.

Para pemuda-pemudi yang belum menikah di Kanagarian Kambang Kecamatan Lengayang, merupakan pemudi yang aktif dan solid serta kompak. Pekerjaan masyarakat Kanagarian Kambang Kecamatan Lengayang umumnya bekerja di bidang; bertani, berkebun, pedagang dan nelayan serta pegawai negeri seperti guru, dan pegawai kantoran serta buruh. Berdasarkan pendidikan masyarakatnya dapat diketahui bahwa masih adanya jumlah masyarakat yang belum tamat SD dan pendidikan hingga tingkat Perguruan Tinggi hampir merata. Seluruh masyarakat adalah beragama Islam. Kemlompok masyarakat di nagari ini menganut sistem Matrilineal (melihat anggota dalam pewarisan dan penentuan anggota keluarga.

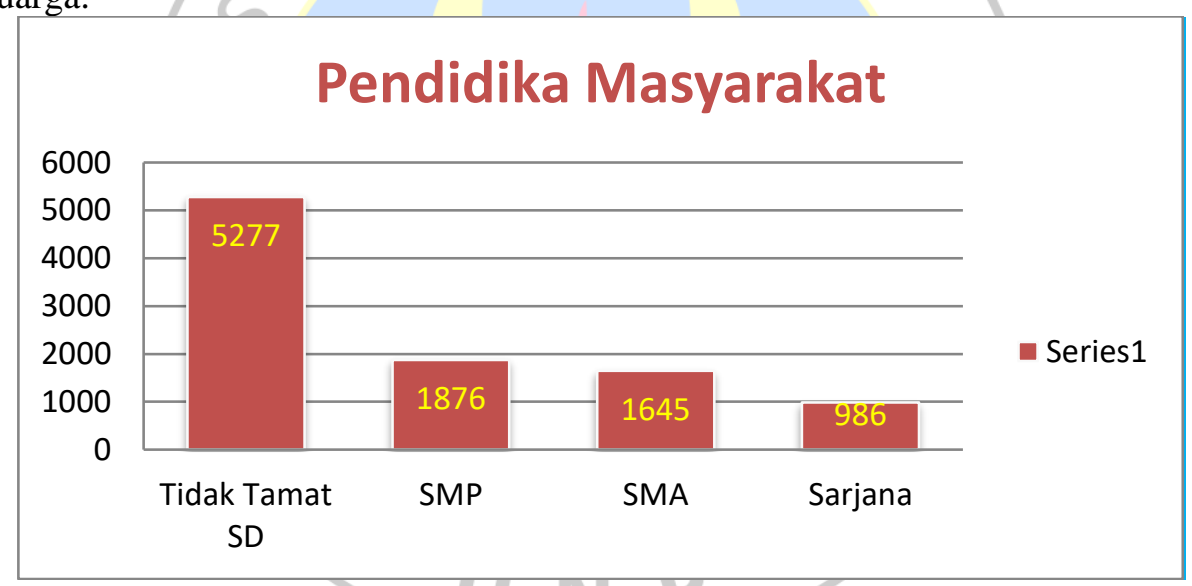

Gambar 1. Diagram Pendidikan Masyarakat

Berdasarkan diagram di atas dapat diketahu bahwa terdapat 5277 jiwa masyarakat Nagari Kambang masih belum sekolah atau tidak tamat SD. Selain itu menunjukkan masih tingginya angka putus sekolah di kalangan masayarakat nagari Kambang.

Terkait dengan pelaksanaan kegiatan ini menujukkan bahwa pentingnya dilaksanakan kegiatan ini karena angka pendidikan masih rendah. Artinya masih terbatasnya pengetahuan masyarakat mengenai pernikahan dan keluarga sakinah mawaddah wa rahmah. Selain itu pelatihan ini sangat dinantikan oleh masyarakat terutama terhadap Calon pengantin, sebab pelatihan ini sevagai bahan tambahan mereka dalam berumah tangga. Melalui kegiatan pelatihan ini tentu menjadi kesempatan bagi mereka bertanya, dan mengemukakan permasalahan yang sering ditemuinya sebelum berkeluarga dan sesudah berkeluarga. Dengan demikian, pelatihan ini menjadi hal penting bagi mereka, sebab berdasarkan data di harian Repubilika, (Ahad, 21 Januari 2017), terdapat 350.000 kasus di Indonesia selama tahun 2016 terjadi kasus perceraian di pengadilan agama.

Pelaksanaan kegiatan pengabdian ini berupa penyuluhan tentang bimbingan pra nikah bagi calon pengantin, disambut hangat dan positif oleh para pemuda-pemudi yang akan menikah. Antusias pemuda-pemudi ini dapat dilihat dalam jumlah peserta yang ikut serta dalam kegiatan ini sejumlah 28

$$
\begin{array}{r}
\text { ABDI: Jurnal Pengabdian dan Pemberdayaan Masyarakat, Vol. } 1 \text { No. } 2 \\
\text { E-ISSN: 2684-8570| ABDI } 2019 \\
\text { Copyright@ 2019, By Author }
\end{array}
$$


orang, terdiri dari 17 orang laki-laki dan 11 orang perempuan. Umumnya peserta kegiatan ini adalah pemuda dan pemudi yang belum menikah. Rata-rata umur mereka adalah 17 tahun hingga 30 tahun. Dua orang diantara mereka adalah perjaka yang sudah tidak memiliki istri lagi.

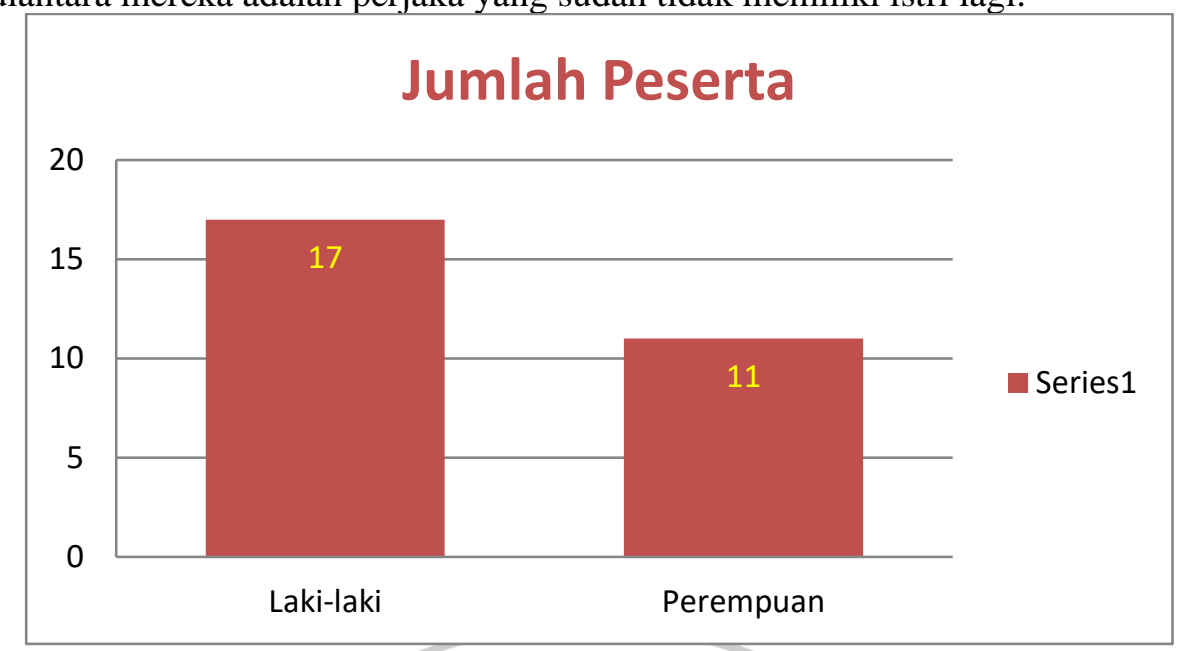

Gambar 2. Diagram Jumlah Peserta

Berdasarkan diagram di atas dapat diketahui bahwa peserta dalam kegiatan ini umumnya berasal dari jenis kelamin laki dan perepuan serta didominasi oleh laki-laki. Angka ini menunjukkan tingginya animo masyarakat mengikutinya, terutama dari kalangan laki-laki sebagai kepala rumah tangga. Kegiatan ini menggunakan metode penyuluhan dan tanya jawab langsung, agar lebih terarah dan memperoleh komunikasi langsung dengan nara sumber, sehingga lebih puas dalam bertanya terkait dengan bimbingan pra-nikah. Selain itu, kegiatan ini mengundang empat orang narasumber yang ahli di bidangnya. Diatara temanya terkait dengan; Membangun Keluarga Sakinah dan Mendidik Anak Secara Islami, Problematika Rumah Tangga dan Kiat-kiat mengatasinya, dan Etika dalam Rumah Tangga. Nara sumber dalam kegiatan ini berasal dari Universitas Negeri Padang. Mereka dari jurusan IAI (Ilmu Agam Islam) Prodi Pendidikan Agam Islam. Materi yang dipilih dalam kegiatan ini sangat didasarkan dari diskusi tim pengusul yang mempertimbangkan keterkaitan hubungan keluarga sakinah dan permasalahan keluarga yang terjadi dalam masyarakat. Materi ini diharapkan mampu menjawab persoalan yang dihadapi oleh keluarga pada saat ini sehingga terbangun keluarga sakinah mawaddah wa rahmah.

Untuk mengetahui tingkat keberhasilan kegiatan ini dapat dilihat dari respon pertanyaan dari peserta kegiatan. Selama kegiatan penyuluhan dilaksanakan, terdapat banyak pertanyaan dari peserta terkait dengan menikah dalam Islam, Terutama mengenai permaslahan dan cara mengatasi masalah dalah rumah tangga, seperti meninggalkan istri dalam waktu beberapa tahun untuk bekerja tanpa menafkahinya, mengatasi cek dalam rumah tangga dan perlunya pengenalan lebih jauh terhadap calon pengantin. Selama kegiatan dilaksanakan peserta menjadi bertambah pemahaman mereka terhadap keluarga. Mereka memahami awalnya berumah tangga itu gampang, ternyata memrlukan ilmu dan pemahaman, serta kesabaran dalam menjalankannya. Acara pelatihan ini dilakukan selama dua hari yaitu hari Jum'at dan Sabtu. Hari Jumat merupakan hari registrasi peserta dan hari Sabtu pelaksanaan kegiatan pelatihan penyuluhan. Acara ini dibuka dan ditutup oleh pak Wali nagari Kambang Kecamatan Lengayang kabupaten Pesisir Selatan. Selain itu juga dilakukan foto bersama peserta dan panitia pelaksana kegiatan ini. Adapun pemateri pertama adalah Al Ikhlas (Bidang kajian Syariah) dengan tema Konsep pernikahan dalam Islam. Dilanjutkan dengan Rangga Satria (Bidang kajian Pendidikan Islam) dengan tema Membina Keluarga Sakinah. Pemateris berikutnya adalah Wirdati (Bidang Kajian Pendidikan Islam) dengan tema Mendidik Anak secara Islami dan pemateri terakhir adalah M.Hidayat (Bidang Kajian Sosiologi-Antropologi) dengan tema Problema Rumah Tangga dan Kiat-kiat mengatasinya serta Etika dalam Rumah tangga. Selesai Acara berfoto bersama peserta dan panitia bersalaman dan pulang ke rumah mereka masing-masing. Berikut foto kegiatan pengabdian ini;

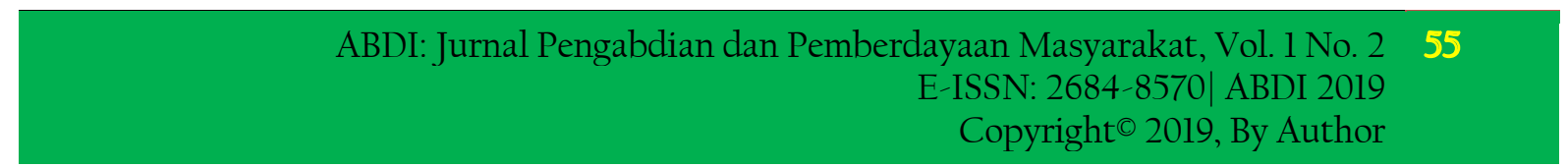



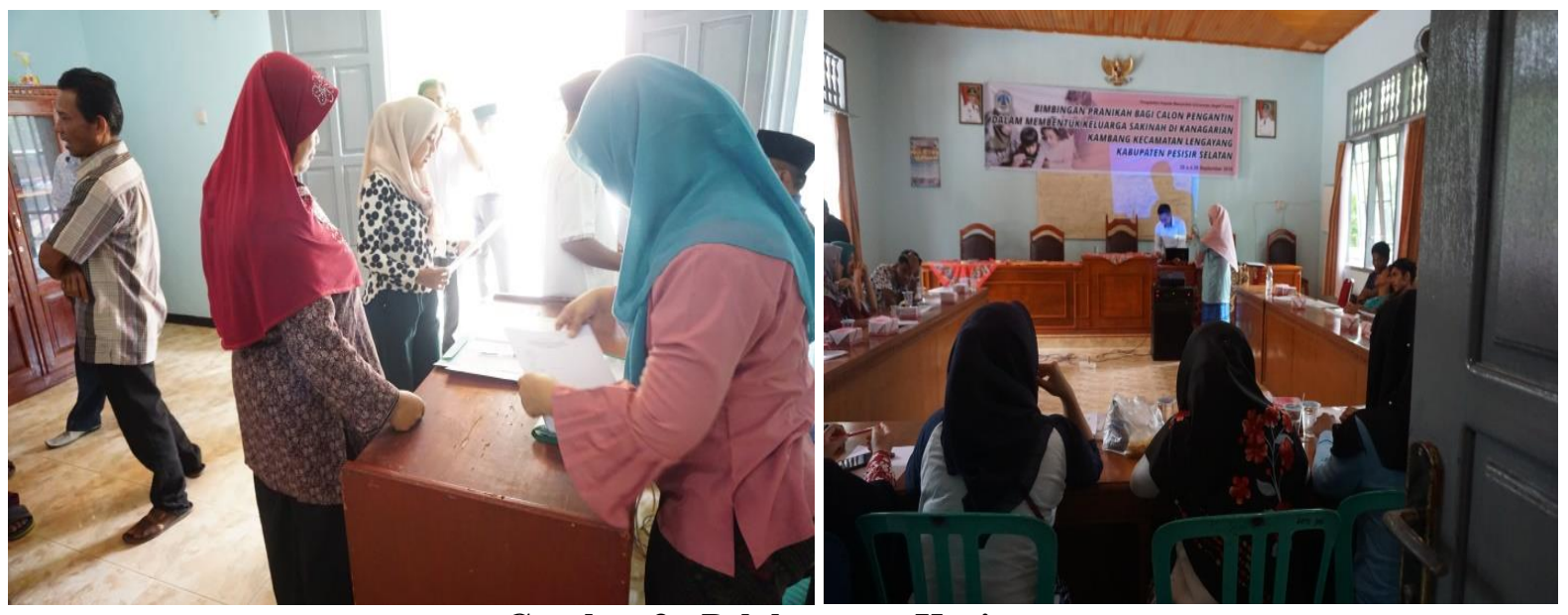

\section{Kesimpulan}

Gambar 3 : Pelaksanaan Kegiatan

Penyuluhan bimbingan pra-nikah bagi calon pengantin dalam membentuk keluarga sakinah di kanagarian Kambang menunjang dalam menyeipakan kelompok rumah tangga yang dapat diberdayakan dalam membentuk keluarga sakinah mawadaah wa rahmah. Pendampingan ini dibutuhkan karena kegiatan ini penting bagi masyarakat setempat ditambah dengan terbatasnya informasi tentang pernikahan di kalangan masyarakatnya. Melalui model ceramah dan diskusi diharapkan dapat langsung memberikan jawaban terhadap persoalan rumah tangga.

\section{Daftar Pustaka}

Al 'Amir. Najib Khalid.(1994). Tarbiyah Rasulullah (terj.). Jakarta : Gema Insani press.

Alkhasyt, Muhammad Usman. (1990). Sulitnya Berumah tangga, Upaya Mengatasinya munurut Qur'an, Hadis dan Ilmu Pengetahuan (terj.). Jakarta : Gema Insani Press

Departemen Agama RI. (2007). Psikologi Perkawinan dan Keluarga. Jakarta: Badan Litbang dan Diklat Departemen Agama.

(2007). Мепијu Keluarga Sakinah. Jakarta: Badan Litbang dan Diklat Deprtemen Agama.

Hakim, M. Arief. (2002). Mendidik Anak Secara Bijak. Bandung: Marja'

Jauzi, Imam Ibnul. (1996). Birrul Walidain, Berbakti Kepada Orang Tua di Kala Hidup dan Sesudah mati (terj.). Surabaya: Pustaka Progresif.

Kementerian Agama RI. (2010). Syaamil Al Qur'an, Miracle The Reference. Bandung: Sygma publishing.

Nasrul, dkk. (2010). Pendidikan Agama Islam Untuk Perguruan Tinggi Umum. Padang: UNP Press.

Syahatah, Husein. (2002). Menjadi Kepala Rumah Tangga Yang Sukses. Jakarta: Gema Insani press.

Sabiq, Sayyid. (2008). Fiqh Sunnah (Terj). Jakarta: Pena Pundi Aksara

Thalib, Muhammad. (1997). 20 Prilaku Durhaka Suami terhadap Isteri. Bandung: Irsyad Baitus Salam . (1997). Mengenal Tipe-Tipe Isteri. Bandung : IBS

. (1995). 40 Tanggung Jawab orang Tua terhadap Anak. Bandung : IBS

. (1997). 15 Penyebab Perceraian dan penanggugulangannya. Bandung:IBS

. (1995). Memahami 20 Sifat Fitrah Anak. Bandung : IBS

Ulwan, Abdullah Nasikh.(1992). Perkawinan Masalah Orang Muda, Orang Tua dan Negara. Jakarta : Gema Insani Press

Yusuf., Husein Muhammad. (1987). Memilih Jodoh dan Tata Cara Meminang dalam Islam. Jakarta : Gema Insani Press. 